\title{
BH3 mimetics: Their action and efficacy in cancer chemotherapy
}

\author{
Wataru Nakajima and Nobuyuki Tanaka* \\ Department of Molecular Oncology, Institute for Advanced Medical Sciences, Nippon Medical School, Japan
}

\begin{abstract}
Evading apoptosis is a hallmark of cancer, and anti-apoptotic BCL-2 family proteins are frequently highly expressed in cancers. In cancer cells, aberrant DNA replication invokes replication-associated DNA damage signaling in cancer cells; however, DNA damage-induced apoptotic signals are masked by such apoptosis evasion systems. Therefore, it is considered that targeting of apoptosis is efficient for cancer cell-selective therapeutic methods. BCL-2 family proteins are critical regulators of mitochondrion-mediated apoptosis, and 'BH3-only' subfamily proteins induce apoptosis by binding to anti-apoptotic BCL-2 family proteins via their $\mathrm{BH} 3$ domain. $\mathrm{BH} 3$ mimetics are small molecules that mimic BH3-proteins by binding to anti-apoptotic BCL-2 family proteins. To date, more than 20 compounds have been identified, and their effects in cancer therapy have been analyzed. In this review, their efficacy in cancer chemotherapy will be discussed.
\end{abstract}

\section{Introduction}

Mechanistic-based molecular-targeted therapies to treat human cancers have undergone rapid development [1]. For example, small molecules specifically blocking certain aspects of signaling pathways associated with tumor growth are widely utilized for cancer chemotherapy, such as cancer-associated tyrosine kinase inhibitors [24]. Furthermore, drugs targeting chromatin modifiers, cancer-specific metabolic regulators, telomerase regulators and immune checkpoint regulators have also been investigated [5-8]. In addition to these approaches, targeting apoptosis regulators has been considered as an attractive option in cancer therapy.

BH3 mimetics are small compounds that antagonize antiapoptotic BCL-2 family proteins, resulting in apoptosis induction in cancer cells $[9,10]$. Recently, several $\mathrm{BH} 3$ mimetics were identified, and accumulating evidence has shown their efficacy in cancer therapy. However, at present, their effects are limited by their target specificity and adverse drug reactions. We present here the recent advances in $\mathrm{BH} 3$ mimetics research, and discuss their efficacy and limitations.

\section{Regulation of apoptosis by BCL-2 family proteins}

Apoptosis is a major barrier to cancer that must be circumvented, and evasion of apoptosis is a hallmark of cancer, causing resistance to cancer chemotherapy $[1,11,12]$. Therefore, therapeutic agents that can overcome the effect of evading apoptosis may be utilized for cancer therapy. BCL-2 family proteins are critical regulators of apoptosis and function immediately upstream of mitochondria. BCL-2 family proteins possess conserved BCL-2 homology $(\mathrm{BH})$ domains and are classified into anti- and pro-apoptotic members that are further subdivided into 'multidomain' proteins, which contain four $\mathrm{BH}$ domains (BH1 to $\mathrm{BH} 4)$, and 'BH3-only' proteins [10,13,14]. Among these proteins, the pro-apoptotic multidomain members BAX and BAK function as mitochondrial executioners and directly open pores in the mitochondrial outer membrane, resulting in the release of the apoptogenic factors such as cytochrome $\mathrm{c}$ and Smac/Diabro. Studies in mice lacking both Bax and Bak showed that Bax and Bak are essential inducers of mitochondrion-mediated apoptosis in response to various stimuli, including DNA damage. In contrast, anti-apoptotic multidomain members, Bcl-2, Bcl-XL and Mcl-1, inhibit the pore formation of Bax and Bak through direct binding [10,13,14]. BH3-only proteins are critical for initiating apoptosis, functioning immediately upstream of multidomain members, and activate Bax and Bak through direct and/or indirect activation [13,15]. Quadruple deficiency of Bim, Bid, Puma and Noxa abrogates apoptosis induced by various stimuli, suggesting the importance of these direct activator type $\mathrm{BH} 3$-only proteins in triggering Bax/Bak-mediated apoptosis induction [16]. In addition to their direct effect, $\mathrm{BH} 3$-only proteins also inactivate antiapoptotic multidomain proteins, resulting in indirect activation of Bax and Bak $[15,16]$. Among BH3-only proteins, BIM and PUMA appear to bind to all anti-apoptotic multidomain proteins with equal affinity, whereas the other members display differential affinity. Particularly, NOXA, an inducer of tumor suppressor p53-mediated apoptosis [17], shows a unique feature in that it does not bind to BCL-2, BCLXL or BCL-W but does bind to MCL-1 and A1 with high affinity [15]. Therefore, it is possible that differences in $\mathrm{BH} 3$ domain structure control altered apoptosis-induction pathways.

\section{BH3 mimetics and their action}

The pro-apoptotic $\mathrm{BH} 3$ domain consists of an amphipathic $\alpha$-helix and binds to the hydrophobic groove, which contains $\mathrm{BH} 1,-3$ and -4 , of anti-apoptotic multidomain proteins, resulting in the release of sequestered pro-apoptotic proteins BAX, BAK, and the activator type $\mathrm{BH} 3$-only proteins $[10,18]$. Released BAX and BAK activate themselves

Correspondence to: Nobuyuki Tanaka, Department of Molecular Oncology, Institute for Advanced Medical Sciences, Nippon Medical School, 1-396 Kosugicho, Nakahara-ku, Kawasaki 211-8533, Japan, Tel: +81-44-733-1860, Fax: +8144-733-1821, E-mail: nobuta@nms.ac.jp

Key words: apoptosis, BCL-2 family proteins, BH3 mimetics, BH3-only proteins, cancer chemotherapy

Received: March 29 2016; Accepted: April 22, 2016; Published: April 26, 2016 
Table 1. BH3 mimetics and their action.

\begin{tabular}{|c|c|c|c|}
\hline BH3 mimetics & Target & Targeting apoptosis in cancer chemotherapy & Limitation in cancer therapy and other characteristics \\
\hline ABT-737 [21] & $\begin{array}{l}\text { BCL-2, BCL-XL, } \\
\text { BCL-W }\end{array}$ & $\begin{array}{l}\text { ABT-737 is mainly active in hematological malignancies, but less } \\
\text { active in solid tumors. Particularly, some small cell lung cancer } \\
\text { (SCLC) cell lines are highly sensitive [40-43]. }\end{array}$ & $\begin{array}{l}\text { ABT-737 is not orally bioavailable, which can limit drug administration } \\
\text { methods particularly in long-term therapy [44]. }\end{array}$ \\
\hline $\begin{array}{l}\text { ABT-263 } \\
\text { (Navitoclax) [44] }\end{array}$ & $\begin{array}{l}\text { BCL-2, BCL-XL, } \\
\text { BCL-W }\end{array}$ & $\begin{array}{l}\text { ABT-263 is mainly active in hematological malignancies but less } \\
\text { active in solid tumors. ABT- } 263 \text { shows limited activity against } \\
\text { advanced and recurrent SCLC [45]. }\end{array}$ & $\begin{array}{l}\text { ABT-263 was highly bound with albumin and an increased albumin } \\
\text { binding accounted for the differential sensitivity of CLL cells } \\
\text { [46]. Inactivation of BCL-XL reduces platelet half-life and causes } \\
\text { thrombocytopenia in a dose-dependent manner [47]. }\end{array}$ \\
\hline ABT-199 [37] & BCL-2 & $\begin{array}{l}\text { ABT-199 efficiently induces apoptosis in BCL2-dependent } \\
\text { hematological malignancies, without causing thrombocytopenia } \\
\text { [37]. }\end{array}$ & $\begin{array}{l}\text { ABT-199 is less sensitivity in solid tumors compared with ABT-263 or } \\
\text { ABT-737 [32-35]. }\end{array}$ \\
\hline WEHI-539 [48] & BCL-XL & WEHI-539 sensitizes colon cancer stem cells to chemotherapy [49]. & Pharmacological inactivation of BCL-XL causes thrombocytopenia [47]. \\
\hline BXI-61, BXI-72 [50] & BCL-XL & $\begin{array}{l}\text { Effects were investigated in lung cancer cell lines, and inhibition } \\
\text { of tumor cell proliferation was demonstrated in vitro and in vivo in } \\
\text { xenograft animal models [50]. }\end{array}$ & \\
\hline $\begin{array}{l}\text { GX15-070 } \\
\text { (Obatoclax) [51] }\end{array}$ & $\begin{array}{l}\text { All of the anti- } \\
\text { apoptotic BCL-2 } \\
\text { family proteins }\end{array}$ & $\begin{array}{l}\text { Because of its ability to bind MCL-1, obatoclax may be particularly } \\
\text { promising for the treatment of solid tumors. Therefore, its efficacy } \\
\text { was investigated in clinical trials for SCLC [52]. }\end{array}$ & $\begin{array}{l}\text { Early clinical trials with obatoclax have indicated neuronal toxicity [52]. } \\
\text { Obatoclax added to topotecan did not exceed the response rate seen with } \\
\text { topotecan alone in patients with relapsed SCLC following the platinum- } \\
\text { based therapy. Currently, there are no open clinical trials with obatoclax } \\
\text { in solid tumors. }\end{array}$ \\
\hline S1 [53] & BCL-2, MCL-1 & $\begin{array}{l}\text { Anti-tumor activity of S1 was shown in a mouse liver carcinoma } \\
\text { xenograft model [54]. }\end{array}$ & $\begin{array}{l}\text { Resistance to S1 has been reported in SCLC by the activation of the } \\
\text { MAPK/ERK pathway and the subsequent phosphorylation of BCL-2 } \\
\text { [55]. S1 increases reactive oxygen species, resulting in initiation of } \\
\text { endoplasmic reticulum (ER) stress [56]. S1-mediated death is in part } \\
\text { because of autophagy through ER stress and disruption of Beclin 1/BCL- } \\
2 \text { interaction [57]. }\end{array}$ \\
\hline JY-1-106 [58] & BCL-XL, MCL-1 & $\begin{array}{l}\text { JY-1-106 was able to suppress tumor growth in a lung cancer } \\
\text { xenograft model [58]. }\end{array}$ & $\begin{array}{l}\text { Data on the specificity and toxicity of JY-1-106 have not yet been } \\
\text { published [58]. }\end{array}$ \\
\hline $\begin{array}{l}\text { Apogossypolone } \\
\text { (ApoG2) [59] }\end{array}$ & BCL-2, MCL-1 & $\begin{array}{l}\text { ApoG2 inhibited the proliferation of nasopharyngeal carcinoma } \\
\text { (NPC) cells in a dose-dependent manner }[59,60] .\end{array}$ & $\begin{array}{l}\text { ApoG2 inhibits the binding of BCL-2 to Beclin 1, inducing autophagy } \\
\text { and radio-sensitizing NPC cells both in vitro and in vivo [61]. However, } \\
\text { several studies have reported that autophagy attenuates apoptosis and } \\
\text { promotes cell survival. }\end{array}$ \\
\hline $\begin{array}{l}\text { BI97C1 (sabutoclax) } \\
{[62]}\end{array}$ & $\begin{array}{l}\text { BCL-2, BCL- } \\
\text { XL, BCL-2A1, } \\
\text { MCL-1 }\end{array}$ & $\begin{array}{l}\text { BI97C1 induce apoptosis in culture cells in a BAX/BAK- and } \\
\text { caspase-9-dependent manner [63]. }\end{array}$ & $\begin{array}{l}\text { BI97C1 had little apoptotic effect on benign prostate tissue in } \\
\text { transforming growth factor } \beta \text { receptor type II in stromal fibroblastic cells } \\
\text { and wild-type mice. BI97C1 was able to block c-Met activation, a critical } \\
\text { axis in PCa metastatic progression [64]. }\end{array}$ \\
\hline TW-37 [65] & $\begin{array}{l}\text { MCL-1, weekly } \\
\text { BCL-2 and BCL- } \\
\text { XL }\end{array}$ & $\begin{array}{l}\text { Effect has been demonstrated in prostate and pancreatic cancer cells } \\
{[65] .}\end{array}$ & $\begin{array}{l}\text { TW-37 were more effective than ABT-263 and also resulted in BAX/ } \\
\text { BAK- and caspase-9-dependent apoptosis [63]. However, such specificity } \\
\text { was generally lost when TW- } 37 \text { was used at high concentrations }(>10 \\
\mu \mathrm{M}) \text {, possibly because of off-target effects [63]. }\end{array}$ \\
\hline MIM1 [66] & MCL-1 & MIM1 induced apoptosis in a MCL-1-dependent leukemia cell line. & $\begin{array}{l}\text { MIM1 induced BAK-dependent apoptosis only at high concentrations } \\
\text { (>10 } \mu \mathrm{M} \text { ) and failed to induce apoptosis in MCL-1-, BCL-2- and } \\
\text { BCL-XL-dependent cell lines. Its potency may be limited and cell-type- } \\
\text { dependent [63]. }\end{array}$ \\
\hline $\begin{array}{l}\text { MS1 (MCL-1-specific } \\
\text { peptide) [67] }\end{array}$ & MCL-1 & $\begin{array}{l}\text { MS1 induced apoptosis in MCL-1-dependent triple-negative breast } \\
\text { cancer cells [33] }\end{array}$ & $\begin{array}{l}\text { Data on the specificity of MS1 have been published only at high } \\
\text { concentrations }(100 \mu \mathrm{M}) \text { in triple-negative breast cancer cells [33]. }\end{array}$ \\
\hline $\begin{array}{l}\text { BH3I-1 and its } \\
\text { structural derivatives } \\
{[68,69]}\end{array}$ & MCL-1 & N.D. & $\begin{array}{l}\text { Neither compound killed Jurkat cells, even at high concentrations } \\
(<30 \mathrm{nM}) \text {, as a single agent or in combination with ABT- } 737 \text { [63]. }\end{array}$ \\
\hline UMI-77 [70] & MCL-1 & $\begin{array}{l}\text { UMI-77 inhibits proliferation of pancreatic cancer cells and induces } \\
\text { intrinsic apoptotic pathways [70]. }\end{array}$ & \\
\hline $\begin{array}{l}\text { Compounds } \\
\text { from Takeda } \\
\text { Pharmaceutical } \\
\text { Company [71] }\end{array}$ & $\begin{array}{l}\text { MCL-1, BCL-XL } \\
\text { (MCL-1/BCL-XL } \\
\text { dual inhibitor) }\end{array}$ & N.D. & \\
\hline \begin{tabular}{l|} 
University of \\
Michigan Compounds \\
{$[72]$}
\end{tabular} & MCL-1 & $\begin{array}{l}\text { This compound inhibited cell proliferation and activated caspase-3 } \\
\text { in a dose-dependent manner [72]. }\end{array}$ & \\
\hline $\begin{array}{l}\text { Marinopyrrole A } \\
\text { (Maritoclax) }[73,74]\end{array}$ & MCL-1 & $\begin{array}{l}\text { Marinopyrrole A induces apoptosis in MCL-1-dependent but } \\
\text { not BCL-2- and BCL-XL-dependent manners in leukemia and } \\
\text { melanoma cells [73,74]. }\end{array}$ & $\begin{array}{l}\text { Marinopyrrole A fails to induce apoptosis of MCL-1-dependent cell lines. } \\
\text { Its potency may be limited and cell type-dependent [75]. }\end{array}$ \\
\hline \begin{tabular}{|l|} 
Compounds \\
from Eutropics \\
Pharmaceuticals [76]
\end{tabular} & $\begin{array}{l}\text { MCL-1 and } \\
\text { weekly BCL-XL }\end{array}$ & $\begin{array}{l}\text { These compounds were found to induce dose-dependent cytochrome } \\
\text { c release and antiproliferative activity against several MCL-1- } \\
\text { dependent cell lines [76]. }\end{array}$ & \\
\hline $\begin{array}{l}\text { AbbVie Compounds } \\
{[77]}\end{array}$ & MCL-1 & N.D. & \\
\hline $\begin{array}{l}\text { Vanderbilt University } \\
\text { Compounds [78] }\end{array}$ & MCL-1 & N.D. & \\
\hline
\end{tabular}


and/or are activated by released $\mathrm{BH} 3$-only proteins to induce apoptosis, suggesting that $\mathrm{BH} 3$ peptides or small compounds structurally similar to the $\mathrm{BH} 3$ domain could be utilized as therapeutic agents against cancer.

In this context, a number of natural or synthetic small molecule inhibitors of anti-apoptotic BCL-2 family proteins were determined, but initially these compounds did not bind to the anti-apoptotic proteins with a high enough affinity and/or activated BAX and BAK to kill target cells efficiently $[19,20]$. Among these compounds, ABT-737 mimics the $\mathrm{BH}$-only proteins by binding to BCL-2, BCL- $\mathrm{X}_{\mathrm{L}}$ and $\mathrm{BCL}-\mathrm{W}$, but not MCL-1, and effectively induces mitochondrion-mediated apoptosis in several cancer cells, particularly MCL-1-suppressed cells [21,22].

\section{Targeting apoptosis in cancer chemotherapy}

In cancer cells, oncogenes induce aberrant DNA replication, which initiates replication-associated DNA-damage signaling, socalled replicative stress [23]. Although DNA-damage signals induce apoptosis in p53-dependent and -independent manners [24], apoptosis is suppressed in cancer cells by various mechanisms including high expression of anti-apoptotic multidomain proteins [1,11]. Therefore, anticancer drugs that damage DNA enhance replicative stress, resulting in induction of apoptosis in cancer cells [25]. In addition, inhibition of cell proliferation by oncogenic kinase inhibitors induces $\mathrm{BH} 3$ only proteins, especially BIM, in several cancer cells $[9,26,27]$. These results suggest the efficacy of agents that target apoptosis in cancer chemotherapy.

As shown in Table 1, a number of $\mathrm{BH} 3$ mimetics were identified and analyzed for their effect against cancer cells and tumors [28,29]. Among these compounds, ABT-263 (navitoclax), an orally available derivative of ABT-737, has been shown to be significantly effective in most CLL patients in clinical trials, and ABT-199 (venetoclax), also has shown to be effective in patients with relapsed or refractory CLL $[13,30]$. Other BH3 mimetics, GX15-070 (obatoclax), Bl-97C1 (sabutoclax), AT-101 (gossypol) and derivatives of AT-101 have also been clinically tested, but their efficacy was only limited. Therefore, combination therapy with another anticancer $\operatorname{drug}(\mathrm{s})$ is now undergoing clinical studies $[13,30]$.

\section{Limitation of BH3 mimetics in cancer therapy}

Extensive analyses of somatic copy-number alterations in human cancers revealed that $M C L-1$ and $B C L-X_{L}$ are enriched in many cancers [31]. Moreover, it has been demonstrated that the survival and proliferation of several cancer cell lines and experimental cancers depend on MCL-1 [32-35]. In contrast to the importance of MCL-1 expression in cancers, clinically-effective BH3 mimetics ABT-263 and ABT-199 cannot affect MCL-1 (Table 1). Therefore, the discovery of $\mathrm{BH} 3$ mimetics that effectively inhibit MCL-1 is still expected at present.

Another problem of $\mathrm{BH} 3$ mimetics in cancer chemotherapy is their side effects. Clinical trials with ABT-263 revealed that dose-dependent thrombocytopenia occurred in all patients [36]. Therefore, the effect of ABT-263 is limited because of its restricted safety dose [13,30]. In contrast, ABT-199 only inhibits BCL-2, but not BCL-X, and does not reduce platelet number compared with ABT-263 [37]; however, it is possible that the efficacy of specific inhibitors of BCL-2 may be limited in lymphocyte and hematopoietic cell malignancies because of specific roles of BCL-2 in lymphoid homeostasis [38].

\section{Conclusion}

In contrast to their exhibited efficacies in cultured cells and experimental tumors, and their theoretically reasonable application for cancer therapy, $\mathrm{BH} 3$ mimetics have only showed limited clinical efficacy in human cancer, especially in hematological malignancies. This limited efficacy may be caused by restricted target specificity and cytotoxicity of currently-available $\mathrm{BH} 3$ mimetics. In this context, recent approaches and discovery of new MCL-1-selective BH3 mimetics may overcome such restricted target problems in combination with BCL-X inhibitors, such as ABT-263 [39]. Moreover, it has been demonstrated that $\mathrm{BH} 3$ mimetics efficiently kill cancer cells in combination with various anti-cancer therapies, especially with oncogenic kinase inhibitors [9]. Analyses of these combination therapies are important for efficient utilization of $\mathrm{BH} 3$ mimetics at their safety dose. If future approaches can overcome these limited efficacies, $\mathrm{BH} 3$ mimetics will be a powerful tool for cancer chemotherapy.

\section{References}

1. Hanahan D, Weinberg RA (2011) Hallmarks of cancer: the next generation. Cell 144 646-674.[Crossref]

2. Hallberg B, Palmer RH (2013) Mechanistic insight into ALK receptor tyrosine kinase in human cancer biology. Nat Rev Cancer 13: 685-700.[Crossref]

3. Pao W, Chmielecki J (2010) Rational, biologically based treatment of EGFR-mutant non-small-cell lung cancer. Nat Rev Cancer 10: 760-774.[Crossref]

4. Zhao Y, Adjei AA (2014) The clinical development of MEK inhibitors. Nat Rev Clin Oncol 11: 385-400.[Crossref]

5. Dawson MA, Kouzarides T (2012) Cancer epigenetics: from mechanism to therapy Cell 150: 12-27.[Crossref]

6. Romaniuk A, Kopczynski P, Ksiazek K, Rubis B1 (2014) Telomerase modulation in therapeutic approach. Curr Pharm Des 20: 6438-6451.[Crossref]

7. Schulze A, Harris AL (2012) How cancer metabolism is tuned for proliferation and vulnerable to disruption. Nature 491: 364-373.[Crossref]

8. Sharma P, Allison JP (2015) Immune checkpoint targeting in cancer therapy: toward combination strategies with curative potential. Cell 161: 205-214.

9. Cragg MS, Harris C, Strasser A, Scott CL (2009) Unleashing the power of inhibitors of oncogenic kinases through BH3 mimetics. Nat Rev Cancer 9: 321-326.[Crossref]

10. Czabotar PE, Lessene G, Strasser A, Adams JM (2014) Control of apoptosis by the BCL-2 protein family: implications for physiology and therapy. Nat Rev Mol Cell Biol 15: 49-63.[Crossref]

11. Hanahan D, Weinberg RA (2000) The hallmarks of cancer. Cell 100: 57-70.[Crossref]

12. Holohan C, Van Schaeybroeck S, Longley DB, Johnston PG (2013) Cancer drug resistance: an evolving paradigm. Nat Rev Cancer 13: 714-726.[Crossref]

13. Delbridge AR, Grabow S, Strasser A, Vaux DL (2016) Thirty years of BCL-2: translating cell death discoveries into novel cancer therapies. Nat Rev Cancer 16: 99109.[Crossref]

14. Youle RJ, Strasser A (2008) The BCL-2 protein family: opposing activities that mediate cell death. NatRev Mol Cell Biol 9: 47-59.[Crossref]

15. Doerflinger M, Glab JA, Puthalakath H (2015) BH3-only proteins: a 20-year stocktake. FEBS J 282: 1006-1016.[Crossref]

16. Chen HC, Kanai M, Inoue-Yamauchi A, Tu HC, Huang Y, et al. (2015) An interconnected hierarchical model of cell death regulation by the BCL-2 family. Nat Cell Biol 17: 1270-1281.[Crossref]

17. Oda E, Ohki R, Murasawa H, Nemoto J, Shibue T, et al. (2000) Noxa, a BH3-only member of the Bcl-2 family and candidate mediator of p53-induced apoptosis. Science 288: 1053-1058.[Crossref]

18. Petros AM, Olejniczak ET, Fesik SW (2004) Structural biology of the Bcl-2 family of proteins. Biochim Biophys Acta 1644: 83-94.[Crossref]

19. Baell JB, Huang DC (2002) Prospects for targeting the Bcl-2 family of proteins to develop novel cytotoxic drugs. Biochem Pharmacol 64: 851-863.[Crossref]

20. Lessene G, Czabotar PE, Colman PM (2008) BCL-2 family antagonists for cancer therapy. Nat Rev Drug Discov 7: 989-1000.[Crossref]

21. Oltersdorf T, Elmore SW, Shoemaker AR, Armstrong RC, Augeri DJ, et al. (2005) An 
inhibitor of Bcl-2 family proteins induces regression of solid tumours. Nature 435: 677-681.[Crossref]

22. van Delft MF, Wei AH, Mason KD, Vandenberg CJ, Chen L, et al. (2006) The BH3 mimetic ABT-737 targets selective Bcl-2 proteins and efficiently induces apoptosis via $\mathrm{Bak} / \mathrm{Bax}$ if Mcl-1 is neutralized. Cancer Cell 10: 389-399.[Crossref]

23. Puigvert JC, Sanjiv K, Helleday T (2016) Targeting DNA repair, DNA metabolism and replication stress as anti-cancer strategies. FEBS J 283: 232-245.[Crossref]

24. Norbury CJ, Zhivotovsky B (2004) DNA damage-induced apoptosis. Oncogene23: 2797-2808.[Crossref]

25. Dobbelstein M, Sørensen CS2 (2015) Exploiting replicative stress to treat cancer. Nat Rev Drug Discov 14: 405-423.[Crossref]

26. Corcoran RB, Cheng KA, Hata AN, Faber AC, Ebi H, et al. (2013) Synthetic lethal interaction of combined BCL-XL and MEK inhibition promotes tumor regressions in KRAS mutant cancer models. Cancer Cell 23: 121-128.[Crossref]

27. Cragg MS, Kuroda J, Puthalakath H, Huang DC, Strasser A (2007) Gefitinib-induced killing of NSCLC cell lines expressing mutant EGFR requires BIM and can be enhanced by BH3 mimetics. PLoS Med 4: 1681-1689.[Crossref]

28. Belmar J, Fesik SW2 (2015) Small molecule Mcl-1 inhibitors for the treatment of cancer. Pharmacol Ther 145: 76-84.[Crossref]

29. Vogler M (2014) Targeting BCL2-Proteins for the Treatment of Solid Tumours. Adv Med 2014: 943648.[Crossref]

30. Vela L, Marzo I (2015) Bcl-2 family of proteins as drug targets for cancer chemotherapy: the long way of BH3 mimetics from bench to bedside. Curr Opin Pharmacol 23: 74-81. [Crossref]

31. Beroukhim R, Mermel CH, Porter D, Wei G, Raychaudhuri S, et al. (2010) The landscape of somatic copy-number alteration across human cancers. Nature 463: 899905.[Crossref]

32. Glaser SP, Lee EF, Trounson E, Bouillet P, Wei A, et al. (2012) Anti-apoptotic Mcl-1 is essential for the development and sustained growth of acute myeloid leukemia. Genes Dev 26: 120-125.[Crossref]

33. Goodwin CM, Rossanese OW, Olejniczak ET, Fesik SW (2015) Myeloid cell leukemia-1 is an important apoptotic survival factor in triple-negative breast cancer. Cell Death Differ 22: 2098-2106.[Crossref]

34. Kelly GL, Grabow S, Glaser SP, Fitzsimmons L, Aubrey BJ, et al. (2014) Targeting of MCL-1 kills MYC-driven mouse and human lymphomas even when they bear mutations in p53. Genes Dev 28: 58-70.[Crossref]

35. Zhang H, Guttikonda S, Roberts L, Uziel T, Semizarov D, et al. (2011) Mcl-1 is critical for survival in a subgroup of non-small-cell lung cancer cell lines. Oncogene 30: 19631968.[Crossref]

36. Gandhi L, Camidge DR, Ribeiro de Oliveira M, Bonomi P, Gandara D, et al. (2011) Phase I study of Navitoclax (ABT-263), a novel Bcl-2 family inhibitor, in patients with small-cell lung cancer and other solid tumors. J Clin Oncol 29: 909-916.[Crossref]

37. Souers AJ, Leverson JD, Boghaert ER, Ackler SL, Catron ND, et al. (2013) ABT199 , a potent and selective BCL-2 inhibitor, achieves antitumor activity while sparing platelets. Nat Med 19: 202-208.[Crossref]

38. Khaled AR, Durum SK (2002) Lymphocide: cytokines and the control of lymphoid homeostasis. Nat Rev Immunol 2: 817-830.[Crossref]

39. Besbes S, Pocard M, Mirshahi M, Billard C (2016) The first MCL-1-selective BH3 mimetics have therapeutic potential for chronic lymphocytic leukemia. Crit Rev Oncol Hematol 100: 32-36.[Crossref]

40. Hann CL, Daniel VC, Sugar EA, Dobromilskaya I, Murphy SC, et al. (2008) Therapeutic efficacy of ABT-737, a selective inhibitor of BCL-2, in small cell lung cancer. Cancer Res 68: 2321-2328.[Crossref]

41. Hauck P, Chao BH, Litz J, Krystal GW (2009) Alterations in the Noxa/Mcl-1 axis determine sensitivity of small cell lung cancer to the BH3 mimetic ABT-737. Mol Cancer Ther 8: 883-892.[Crossref]

42. Lin X, Morgan-Lappe S, Huang X, Li L, Zakula DM, et al. (2007) 'Seed' analysis of off-target siRNAs reveals an essential role of Mcl-1 in resistance to the small-molecule Bcl-2/Bcl-XL inhibitor ABT-737. Oncogene 26: 3972-3979.[Crossref]

43. Tahir SK, Yang X, Anderson MG, Morgan-Lappe SE, Sarthy AV, et al. (2007) Influence of Bcl-2 family members on the cellular response of small-cell lung cancer cell lines to ABT-737. Cancer Res 67: 1176-1183.[Crossref]
44. Tse C, Shoemaker AR, Adickes J, Anderson MG, Chen J, et al. (2008) ABT-263: a potent and orally bioavailable Bcl-2 family inhibitor. Cancer Res 68: 3421-3428. [Crossref]

45. Rudin CM, Hann CL, Garon EB, Ribeiro de Oliveira M, Bonomi PD, et al. (2012) Phase II study of single-agent navitoclax (ABT-263) and biomarker correlates in patients with relapsed small cell lung cancer. Clin Cancer Res 18: 3163-3169.[Crossref]

46. Vogler M, Furdas SD, Jung M, Kuwana T, Dyer MJ, et al. (2010) Diminished sensitivity of chronic lymphocytic leukemia cells to ABT-737 and ABT-263 due to albumin binding in blood. Clin CancerRes 16: 4217-4225.[Crossref]

47. Mason KD, Carpinelli MR, Fletcher JI, Collinge JE, Hilton AA, et al. (2007) Programmed anuclear cell death delimits platelet life span. Cell 128: 1173-1186. [Crossref]

48. Lessene G, Czabotar PE, Sleebs BE, Zobel K, Lowes KN, et al. (2013) Structureguided design of a selective BCL-X(L) inhibitor. Nat Chem Biol 9: 390-397.[Crossref]

49. Colak S, Zimberlin CD, Fessler E, Hogdal L, Prasetyanti PR, et al. (2014) Decreased mitochondrial priming determines chemoresistance of colon cancer stem cells. Cell Death Differ 21: 1170-1177.[Crossref]

50. Park D, Magis AT, Li R, Owonikoko TK, Sica GL, et al. (2013) Novel small-molecule inhibitors of Bcl-XL to treat lung cancer. Cancer Res 73: 5485-5496.[Crossref]

51. Nguyen M, Marcellus RC, Roulston A, Watson M, Serfass L, et al. (2007) Small molecule obatoclax (GX15-070) antagonizes MCL-1 and overcomes MCL-1-mediated resistance to apoptosis. Proc Natl Acad Sci U S A 104: 19512-19517.[Crossref]

52. Hwang JJ, Kuruvilla J, Mendelson D, Pishvaian MJ, Deeken JF, et al. (2010) Phase I dose finding studies of obatoclax (GX15-070), a small molecule pan-BCL-2 family antagonist, in patients with advanced solid tumors or lymphoma. Clin Cancer Res 16: 4038-4045.[Crossref]

53. Zhang Z, Jin L, Qian X, Wei M, Wang Y, et al. (2007) Novel Bcl-2 inhibitors: Discovery and mechanism study of small organic apoptosis-inducing agents. Chembiochem 8 : 113-121.[Crossref]

54. Song T, Chang X, Zhang Z, Liu Y, Shen X (2012) S1, a novel pan-BH3 mimetic, induces apoptosis in Mcl-1-overexpressing cells through Bak. J Pharmacol Sci 119: 330-340.[Crossref]

55. Liu Y, Zhang Z, Song T, Liang F, Xie M, et al. (2013) Resistance to BH3 mimetic S1 in SCLC cells that up-regulate and phosphorylate Bcl-2 through ERK1/2. Br J Pharmacol 169: 1612-1623.[Crossref]

56. Soderquist R, Pletnev AA, Danilov AV, Eastman A (2014) The putative BH3 mimetic S1 sensitizes leukemia to ABT-737 by increasing reactive oxygen species, inducing endoplasmic reticulum stress, and upregulating the BH3-only protein NOXA. Apoptosis 19: 201-209.[Crossref]

57. Zhong JT, Xu Y, Yi HW, Su J, Yu HM, et al. (2012) The BH3 mimetic S1 induces autophagy through ER stress and disruption of Bcl-2/Beclin 1 interaction in human glioma U251 cells. Cancer Lett 323: 180-187.[Crossref]

58. Cao X, Yap JL, Newell-Rogers MK, Peddaboina C, Jiang W, et al. (2013) The nove BH3 alpha-helix mimetic JY-1-106 induces apoptosis in a subset of cancer cells (lung cancer, colon cancer and mesothelioma) by disrupting Bcl-xL and Mcl-1 proteinprotein interactions with Bak. Mol Cancer 12: 42.[Crossref]

59. Arnold AA, Aboukameel A, Chen J, Yang D, Wang S, et al. (2008) Preclinical studies of Apogossypolone: a new nonpeptidic pan small-molecule inhibitor of Bcl-2, Bcl-XL and Mcl-1 proteins in Follicular Small Cleaved Cell Lymphoma model. Mol Cancer 7: 20.[Crossref]

60. Hu ZY, Sun J, Zhu XF, Yang D, Zeng YX (2009) ApoG2 induces cell cycle arrest of nasopharyngeal carcinoma cells by suppressing the c-Mycsignaling pathway. $J$ Transl Med 7: 74.[Crossref]

61. He JH, Liao XL, Wang W, Li DD, Chen WD, et al. (2014) Apogossypolone, a smallmolecule inhibitor of Bcl-2, induces radiosensitization of nasopharyngeal carcinoma cells by stimulating autophagy. Int JOncol45: 1099-1108.[Crossref]

62. Wei J, Stebbins JL, Kitada S, Dash R, Placzek W, et al. (2010) BI-97C1, an optically pure Apogossypol derivative as pan-active inhibitor of antiapoptotic B-cell lymphoma/ leukemia-2 (Bcl-2) family proteins. J Med Chem 53: 4166-4176.[Crossref]

63. Varadarajan S, Vogler M, Butterworth M, Dinsdale D, Walensky LD, et al. (2013) Evaluation and critical assessment of putative MCL-1 inhibitors. Cell Death Differ 20: 1475-1484.[Crossref]

64. Varadarajan S, Butterworth M, Wei J, Pellecchia M, Dinsdale D, et al. (2013) Sabutoclax (BI97C1) and BI112D1, putative inhibitors of MCL-1, induce mitochondrial 
fragmentation either upstream of or independent of apoptosis. Neoplasia 15: 568-578. [Crossref]

65. Wang G, Nikolovska-Coleska Z, Yang CY, Wang R, Tang G, et al. (2006) Structurebased design of potent small-molecule inhibitors of anti-apoptotic Bcl-2 proteins. $J$ Med Chem 49: 6139-6142.[Crossref]

66. Cohen NA, Stewart ML, Gavathiotis E, Tepper JL, Bruekner SR, et al. (2012) A competitive stapled peptide screen identifies a selective small molecule that overcomes MCL-1-dependent leukemia cell survival. Chem Biol 19: 1175-1186.[Crossref]

67. Foight GW, Ryan JA, Gullá SV, Letai A, Keating AE (2014) Designed BH3 peptides with high affinity and specificity for targeting Mcl-1 in cells. ACS Chem Biol 9: 19621968.[Crossref]

68. Bernardo PH, Sivaraman T, Wan KF, Xu J, Krishnamoorthy J, et al. (2010) Structural insights into the design of small molecule inhibitors that selectively antagonize Mcl-1. J Med Chem 53: 2314-2318.[Crossref]

69. Lugovskoy AA, Degterev AI, Fahmy AF, Zhou P, Gross JD, et al. (2002) A novel approach for characterizing protein ligand complexes: molecular basis for specificity of small-molecule Bcl-2 inhibitors. J Am Chem Soc 124: 1234-1240.[Crossref]

70. Abulwerdi F, Liao C, Liu M, Azmi AS, Aboukameel A, et al. (2014) A novel smallmolecule inhibitor of mcl-1 blocks pancreatic cancer growth in vitro and in vivo. $\mathrm{Mol}$ Cancer Ther 13: 565-575.[Crossref]

71. Tanaka Y, Aikawa K, Nishida G, Homma M, Sogabe S, et al. (2013) Discovery of potent $\mathrm{Mcl}-1 / \mathrm{Bcl}-\mathrm{xL}$ dual inhibitors by using a hybridization strategy based on structural analysis of target proteins. J Med Chem 56: 9635-9645.[Crossref]
72. Abulwerdi FA, Liao C, Mady AS, Gavin J, Shen C, et al. (2014) 3-Substituted-N(4-hydroxynaphthalen-1-yl)arylsulfonamides as a novel class of selective Mcl-1 inhibitors: structure-based design, synthesis, SAR, and biological evaluation. $J$ Med Chem 57: 4111-4133.[Crossref]

73. Doi K, Li R, Sung SS, Wu H, Liu Y, et al. (2012) Discovery of marinopyrroleA (maritoclax) as a selective Mcl-1 antagonist that overcomes ABT-737 resistance by binding to and targeting Mcl-1 for proteasomal degradation. J Biol Chem 287: 1022410235.[Crossref]

74. Pandey MK, Gowda K, Doi K, Sharma AK, Wang HG, et al. (2013) Proteasomal degradation of Mcl-1 by maritoclax induces apoptosis and enhances the efficacy of ABT-737 in melanoma cells. PLoS One 8: e78570.[Crossref]

75. Eichhorn JM, Alford SE, Hughes CC, Fenical W, Chambers TC (2013) Purported Mcl1 inhibitor marinopyrrole A fails to show selective cytotoxicity for Mcl-1-dependent cell lines. Cell Death Dis 4: e880.[Crossref]

76. Richard DJ, Lena R, Bannister T, Blake N, Pierceall WE, et al. (2013) Hydroxyquinolinederived compounds and analoguing of selective Mcl-1 inhibitors using a functional biomarker. Bioorg Med Chem 21: 6642-6649. [Crossref]

77. Petros AM, Swann SL, Song D, Swinger K, Park C, et al. (2014) Fragment-based discovery of potent inhibitors of the anti-apoptotic MCL-1 protein. Bioorg Med Chem Lett 24: 1484-1488.[Crossref]

78. Friberg A, Vigil D, Zhao B, Daniels RN, Burke JP, et al. (2013) Discovery of poten myeloid cell leukemia 1 (Mcl-1) inhibitors using fragment-based methods and structure-based design. J Med Chem 56: 15-30.[Crossref]

Copyright: $@ 2016$ Nakajima W. This is an open-access article distributed under the terms of the Creative Commons Attribution License, which permits unrestricted use, distribution, and reproduction in any medium, provided the original author and source are credited. 